\title{
Uji Klinik Perbandingan Pengobatan Skabies antara Permethrin 5\% dan Kombinasi Permethrin 5\% dengan Asam Usnat 1\%
}

Clinical Trial Comparing Effectiveness Therapy of Scabies Between 5\% Permethrin and Combination of 5\% Permethrin with 1\% Usnic Acid

\author{
Amir Hamzah $^{1 *}$, Muchtan Sujatno ${ }^{2}$, Diana K Jasaputra ${ }^{2}$, Savitri R Wardhani ${ }^{2}$, Renny \\ Anggraeni $^{2}$ \\ ${ }^{1}$ Departement of Dermatovenereology of Medicine Maranatha Christian University \\ ${ }^{2}$ Faculty of medicine Maranatha Christian University \\ Jl. Prof. Drg. Suria Sumantri MPH no 65 Bandung 40164 Indonesia \\ *Corresponding author \\ Email: amierhz75@gmail.com
}

Received: August 30, 2020

Accepted: August 5, 2021

\begin{abstract}
Abstrak
Penyakit skabies adalah penyakit kulit menular yang disebabkan oleh parasit Sarcoptes scabiei. Prevalensi penyakit skabies di Indonesia 4,60-12,95\% dan menduduki urutan ke tiga dari 12 penyakit kulit tersering. Saat ini pengembangan obat antiskabies masih terus dilakukan antara lain dengan menggunakan obat Permethrin 5\% dan Permethrin 5\% dengan kombinasi Asam Usnat 1\%. Penelitian ini bertujuan mengetahui perbandingan efektivitas antara Permethrin 5\% dan kombinasi Permethrin 5\%-Asam Usnat 1\% pada penderita skabies. Metode penelitian menggunakan desain uji klinik fase III acak tersamar ganda, yang dilakukan pada penderita skabies di Pondok Pesantren Nurul Iman Cibaduyut Bandung yang dinilai berdasarkan efektivitasnya terhadap gejala klinis (tanda cardinal) dan hasil uji mikroskop pada kulit penderita untuk parasit Sarcoptes scabiei. Peneliti maupun subjek penelitian tidak mengetahui obat yang diberikan. Enam puluh sampel uji diberi Label obat antiskabies A dan antiskabies B. Hasil yang didapat adalah pada pemberian terapi krim B yang mengandung kombinasi Permethrin 5\% dan Asam Usnat 1\% lebih cepat menunjukkan kesembuhan $(\mathrm{p}<0,05)$ dibandingkan dengan pemberian terapi krim A yang mengandung Permethrin $5 \%$ pada penderita skabies, dinilai dengan menghilangnya gatal dan lesi pada penderita. Simpulan, pemberian kombinasi Permethrin 5\% dan Asam Usnat 1\% lebih efektif dibandingkan Permethrin 5\% saja.
\end{abstract}

Kata Kunci: Skabies, Sarcoptes Scabei, Permethrin, Asam Usnat

\begin{abstract}
Scabies is an infectious skin disease caused by Sarcoptes scabiei parasites. The prevalence of scabies in Indonesia is 4.60-12.95\% and occupies the third of the 12 most common skin diseases. Nowadays the development of an antiscabies drug is still carried out, among others, using 5\% Permethrin drug and 5\% Permethrin with 1\% usnic acid combination. The study aims to know the effectiveness of the Permethrin 5\% efficacy and the combination of Permethrin 5\%-Usnic acid 1\% in patients with scabies. This method of research using design of double blind randomized controlled trial, that conducted in patients with scabies at Pondok Pesantren Nurul Iman Cibaduyut Bandung and based on its effectiveness of clinical symptoms
\end{abstract}




\section{Research Article}

(cardinal sign) and microscope test results in the sufferer's skin for Sarcoptes scabiei parasites. Sixty samples were given the drug label antiscabies $A$ and $B$. The results of the study of cream therapy $B$ containing the combination of Permethrin 5\% and usnic acid $1 \%$ show more recovery $(p<0.05)$ compared with the treatment of cream A therapy that contains $5 \%$ Permethrin, judged by relieving itching and lesions in patients. In conclusion, 5\% Permethrin with $1 \%$ usnic acid combination more effective compared with 5\% Permethrin.

Keywords : Scabies, Sarcoptes scabei, Permethrin, Usnic acid

\section{Pendahuluan}

Skabies masih merupakan masalah kesehatan di negara berkembang khususnya di Indonesia. Prevalensi skabies di berbagai negara berkembang adalah 6 - 27\%, sedangkan di Indonesia diketahui sebesar 4,60 - 12,95\%. ${ }^{1,2}$ Di Pulau Jawa skabies ditemukan pada daerah kumuh dan pondok pesantren (ponpes). ${ }^{3}$ Pemeriksaan terhadap 75 orang santri ponpes di wilayah Parung Bogor Jawa Barat menunjukkan bahwa prevalensi penyakit skabies adalah $65,30 \% .^{4}$

Skabies tidak membahayakan jiwa, namun penyakit skabies perlu mendapatkan perhatian karena tingkat penularannya yang tinggi serta dapat mengganggu kualitas hidup sehari-hari khususnya bagi para santri yang sedang belajar di pondok pesantren. Pemberian obat topikal merupakan bentuk terapi standar antiskabies. Salah satu obat skabies yang sering digunakan adalah Permethrin. Kepatuhan penderita sangat penting untuk kesembuhan, dengan kurangnya pengawasan di ponpes, ada kemungkinan kurangnya kepatuhan pemberian obat. Oleh karena itu, diperlukan pengembangan obat antiskabies dengan efektivitas yang lebih baik. ${ }^{5}$

Krim Permethrin 5\%, dioleskan ke seluruh tubuh. Setelah 10 jam, krim Permethrin dapat dibersihkan dengan sabun. Permethrin mempunyai aktivitas insektisida yang luas dan bekerja dengan cara mengganggu alur masuk natrium ke dalam membran sel sehingga menyebabkan paralisis neurologis dan kematian tungau. Efek samping dapat berupa sensasi seperti terbakar dan tertusuk terutama pada infeksi yang berat. Pengolesan ke-dua dapat dilakukan satu minggu kemudian dan hanya perlu dilakukan apabila terdapat tanda-tanda kegagalan terapi. Kasus-kasus skabies yang resisten terhadap Gameksan berhasil diobati dengan Permethrin. Hingga saat ini belum terdapat laporan resistensi terhadap Permethrin. ${ }^{67,8}$

Permethrin termasuk kelompok obat piretroid. Piretroid adalah bahan kimia sintetis yang memiliki efek seperti ekstrak alami dari bunga Krisan. Permethrin semula digunakan untuk mengendalikan serangga. Permethrin dapat memengaruhi serangga jika serangga makan atau menyentuhnya. Permethrin dapat memengaruhi sistem saraf serangga, menyebabkan 


\section{Research Article}

kejang otot, kelumpuhan, dan kematian. Permethrin membunuh Sarcoptes scabiei dan telurnya. Anak-anak berusia 2 bulan atau lebih dapat diobati dengan Permethrin. ${ }^{6}$

Asam usnat merupakan turunan dibenzofuran alami yang ditemukan dalam beberapa spesies lumut dengan rumus kimia $\mathrm{C} 18 \mathrm{H} 16 \mathrm{O} 7$. Asam usnat untuk pertama kalinya berhasil diisolasi oleh ilmuwan Jerman W. Knop pada 1844. Asam usnat diidentifikasi dari banyak lumut termasuk Usnea, Cladonia, Hypotrachyna, Lecanora, Ramalina, Evernia, Parmelia, dan Alectoria. Asam usnat memiliki aktivitas antibakteri. ${ }^{8}$

Penelitan ini bertujuan untuk membandingkan efektivitas obat Permethrin 5\% dengan obat kombinasi Permethrin 5\% dan Asam Usnat 1\% pada penderita skabies.

\section{Metode}

Penelitian ini merupakan penelitian uji klinik fase III acak tersamar ganda (double blind randomized controlled trial), menggunakan tabel randomisasi sehingga baik peneliti maupun subjek penelitian tidak mengetahui obat yang diberikan. Krim diberikan label krim antiskabies A dan B. Krim antiskabies A adalah Permethrin 5\% dan krim antiskabies B adalah kombinasi Permethrin 5\% dengan Asam Usnat 1\%. Penelitian ini telah memperoleh persetujuan dari Komisi Etik Penelitian FK UKM-RSI (NO: 003/KEP/III/2016).

Kriteria inklusi pada penelitian ini adalah penderita skabies laki-laki atau perempuan, usia >2 tahun (6-20 tahun) dengan gejala klinis yang khas (tanda kardinal skabies minimal 2), dapat disertai hasil pemeriksaan penunjang dengan mikroskopis, ditemukan adanya tungau Sarcoptes scabiei, penderita tidak menggunakan preparat topikal lainnya sejak 2 minggu sebelumnya, bersedia ikut dalam penelitian dan menandatangani formulir informed consent. Kriteria eksklusi pada penelitian ini adalah penderita yang menderita penyakit inflamasi/ infeksi kulit lain yang ditegakkan berdasarkan anamnesis dan pemeriksaan fisik, penderita yang sudah mendapat pengobatan antiskabies sebelumnya, dan penderita yang sementara dalam perlakuan mengalami efek samping obat.

Seluruh subjek yang telah memenuhi kriteria inklusi sekitar 60 orang terbagi secara random menjadi dua kelompok dan penelitian dilanjutkan dengan mengisi kuesioner mengenai data pribadi dan riwayat penyakit serta pengobatan, kemudian anamnesis penderita dicatat, juga dilakukan pemeriksaan fisik dan penilaian status dermatologikus berupa adanya papula, vesikel, nodul, dan kanalikuli pada seluruh tubuh serta ditunjang pemeriksaan mikroskopis kulit (scrapping). Pengambilan gambar lesi kulit dengan menggunakan kamera digital. 


\section{Research Article}

Krim yang telah dilabel krim A dan B diberikan kepada subjek untuk dioleskan pada malam hari di seluruh tubuh sekali saja dan dibiarkan sekitar 10 jam, selanjutnya hasil dilihat seminggu kemudian. Parameter keluaran yang akan diamati untuk menunjukkan efektivitas terapi adalah berdasarkan berkurangnya gejala klinik dan hasil laboratorium yang dinilai dengan skor, sebagai berikut:

1. Hilangnya keluhan gatal dan hilangnya lesi diberi skor 1

2. Keluhan gatal yang masih ada atau berkurang atau lesi masih ada atau berkurangnya lesi diberi skor 2

Data yang didapat diolah menggunakan Statistical Package for Social Science (SPSS) versi 12. Metode statistik yang digunakan adalah perhitungan nilai rerata, simpang baku, sebaran frekuensi dan uji statistik. Uji statistik yang digunakan adalah Wilcoxon Signed Rank Test dan Kolmogorov-Smirnov Test dengan tingkat kemaknaan $\mathrm{p}<0,05$.

\section{Hasil}

Hasil penelitian memperlihatkan skor perbaikan yang bermakna bagi seluruh penderita skabies, baik dengan pemberian terapi krim A maupun dengan terapi krim B. Akan tetapi pemberian krim B memberikan hasil skor yang lebih baik dibandingkan dengan skor terapi krim A masing-masing adalah 1,4 dan 1,7.

Pemberian terapi krim B memberikan kesembuhan penderita yang ditandai dengan hilangnya gejala gatal dan lesi sebanyak 17 orang dari 30 orang subjek penelitian, atau sebesar $56,67 \%$. Pemberian terapi krim A memberikan kesembuhan penderita yang ditandai dengan hilangnya gejala gatal dan lesi sebanyak 9 orang dari 30 orang subjek penelitian, atau sebesar $30 \%$. Hal ini menunjukkan bahwa pada penelitian ini terapi krim B menunjukan skor lebih baik secara signifikan $(p<0,05)$ dibandingkan pemberian terapi krim A. Selama penelitian kedua krim antiskabies baik A maupun B tidak memberikan efek samping seperti alergi maupun gangguan syaraf berupa melemahnya otot.

Hasil penelitian berupa skor perbaikan dengan pemberian terapi krim A maupun dengan terapi krim B ditunjukkan pada tabel 1. 
Tabel 1 Skor Hasil Penelitian Perbandingan Antiskabies Krim A dan Krim B

\begin{tabular}{|c|c|c|c|c|c|c|c|c|c|c|}
\hline No & $\mathrm{SP}$ & $\begin{array}{c}\text { Umur } \\
\text { (tahun) }\end{array}$ & $\begin{array}{c}\text { Jenis } \\
\text { Kelamin }\end{array}$ & Terapi & Skor & SP & $\begin{array}{c}\text { Umur } \\
\text { (tahun) }\end{array}$ & $\begin{array}{c}\text { Jenis } \\
\text { Kelamin }\end{array}$ & Terapi & Skor \\
\hline 1 & 7 & 16 & $\mathrm{P}$ & $\mathrm{A}$ & 1 & 1 & 17 & $\mathrm{P}$ & B & 1 \\
\hline 2 & 12 & 16 & $\mathrm{P}$ & A & 2 & 3 & 17 & $\mathrm{P}$ & B & 1 \\
\hline 3 & 14 & 15 & $\mathrm{P}$ & A & 1 & 13 & 14 & $\mathrm{P}$ & B & 2 \\
\hline 4 & 19 & 19 & $\mathrm{P}$ & A & 1 & 15 & 14 & $\mathrm{P}$ & B & 1 \\
\hline 5 & 20 & 14 & $\mathrm{P}$ & A & 2 & 18 & 14 & $\mathrm{P}$ & B & 2 \\
\hline 6 & 26 & 12 & $\mathrm{P}$ & A & 2 & 22 & 14 & $\mathrm{P}$ & B & 2 \\
\hline 7 & 36 & 13 & $\mathrm{~L}$ & A & 2 & 28 & 13 & $\mathrm{P}$ & B & 2 \\
\hline 8 & 39 & 12 & $\mathrm{~L}$ & A & 2 & 29 & 13 & $\mathrm{P}$ & B & 2 \\
\hline 9 & 43 & 16 & $\mathrm{~L}$ & A & 2 & 33 & 12 & $\mathrm{P}$ & B & 1 \\
\hline 10 & 44 & 13 & $\mathrm{~L}$ & A & 2 & 34 & 13 & $\mathrm{P}$ & B & 2 \\
\hline 11 & 45 & 13 & $\mathrm{~L}$ & A & 1 & 38 & 13 & $\mathrm{~L}$ & B & 2 \\
\hline 12 & 46 & 13 & $\mathrm{~L}$ & A & 2 & 47 & 13 & $\mathrm{~L}$ & B & 1 \\
\hline 13 & 49 & 13 & $\mathrm{~L}$ & A & 2 & 54 & 13 & $\mathrm{~L}$ & B & 2 \\
\hline 14 & 52 & 13 & $\mathrm{~L}$ & A & 1 & 55 & 13 & $\mathrm{~L}$ & B & 1 \\
\hline 15 & 53 & 13 & $\mathrm{~L}$ & A & 2 & 58 & 14 & $\mathrm{~L}$ & B & 1 \\
\hline 16 & 56 & 13 & $\mathrm{~L}$ & A & 2 & 85 & 14 & $\mathrm{~L}$ & B & 2 \\
\hline 17 & 82 & 12 & $\mathrm{~L}$ & A & 2 & 68 & 14 & $\mathrm{~L}$ & B & 2 \\
\hline 18 & 71 & 12 & $\mathrm{~L}$ & A & 1 & 72 & 12 & $\mathrm{~L}$ & B & 1 \\
\hline 19 & 74 & 12 & $\mathrm{~L}$ & A & 2 & 73 & 12 & $\mathrm{~L}$ & B & 1 \\
\hline 20 & 77 & 12 & $\mathrm{~L}$ & A & 2 & 76 & 12 & $\mathrm{~L}$ & B & 1 \\
\hline 21 & 79 & 12 & $\mathrm{~L}$ & A & 1 & 78 & 13 & $\mathrm{~L}$ & B & 1 \\
\hline 22 & 67 & 13 & $\mathrm{~L}$ & A & 2 & 80 & 12 & $\mathrm{~L}$ & B & 1 \\
\hline 23 & 81 & 12 & $\mathrm{~L}$ & A & 1 & 84 & 12 & $\mathrm{~L}$ & B & 1 \\
\hline 24 & 105 & 14 & $\mathrm{~L}$ & A & 2 & 65 & 13 & $\mathrm{~L}$ & B & 2 \\
\hline 25 & 103 & 13 & $\mathrm{~L}$ & A & 1 & 102 & 12 & $\mathrm{~L}$ & B & 1 \\
\hline 26 & 101 & 11 & $\mathrm{~L}$ & A & 2 & 104 & 12 & $\mathrm{~L}$ & B & 2 \\
\hline 27 & 107 & 12 & $\mathrm{~L}$ & A & 2 & 106 & 13 & $\mathrm{~L}$ & B & 1 \\
\hline 28 & 115 & 13 & $\mathrm{~L}$ & A & 2 & 108 & 12 & $\mathrm{~L}$ & B & 1 \\
\hline 29 & 117 & 15 & $\mathrm{~L}$ & A & 2 & 112 & 12 & $\mathrm{~L}$ & B & 2 \\
\hline \multirow[t]{2}{*}{30} & 119 & 12 & $\mathrm{~L}$ & A & 2 & 114 & 13 & $\mathrm{~L}$ & B & 1 \\
\hline & & & Rerata & & 1,7 & & & Rerata & & 1,4 \\
\hline
\end{tabular}

Pada nilai skor kedua kelompok perlakuan telah dilakukan uji normalitas dan memperlihatkan bahwa data kedua kelompok tersebut tidak normal. Oleh karena itu, data tersebut kemudian diuji dengan menggunakan uji non parametrik Mann Whitney. ${ }^{6}$

Beberapa dokumentasi hasil penelitian berupa perbaikan lesi dengan pemberian terapi krim A maupun dengan terapi krim B ditunjukkan pada Gambar 1. 


\begin{tabular}{|l|}
\hline Research Article \\
\hline
\end{tabular}

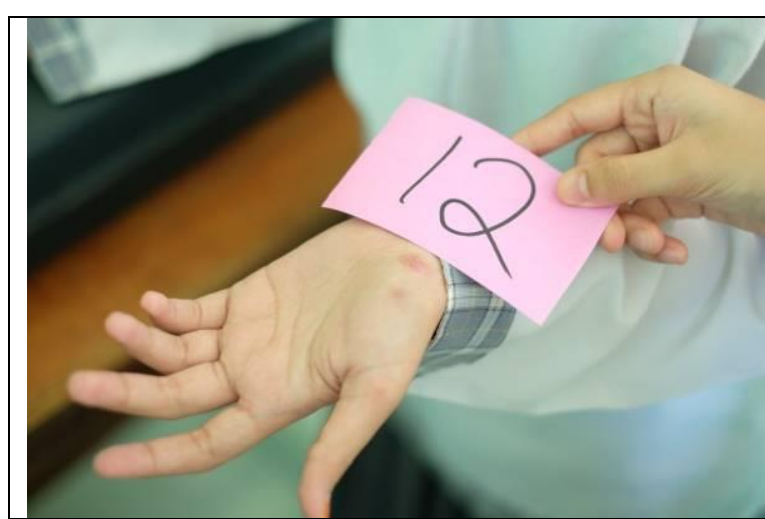

Sebelum terapi A

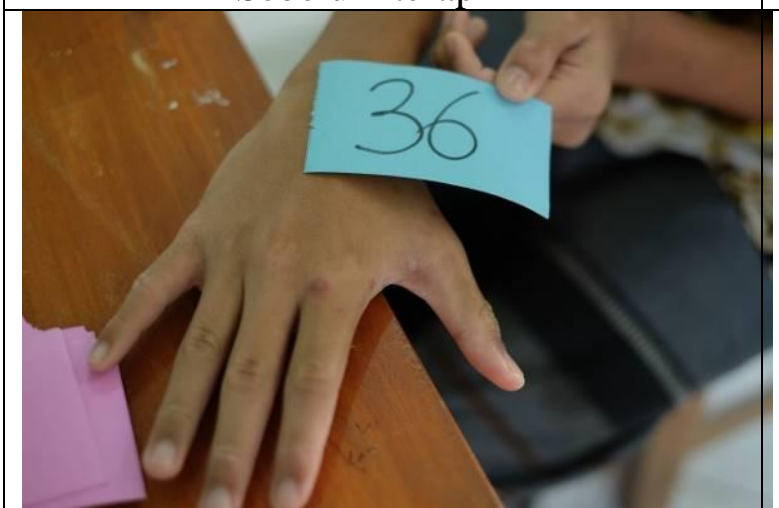

Sebelum terapi A

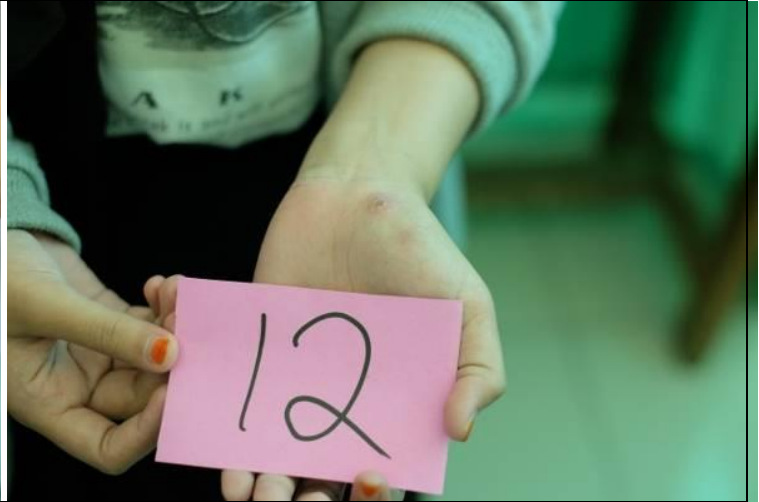

Sesudah terapi A

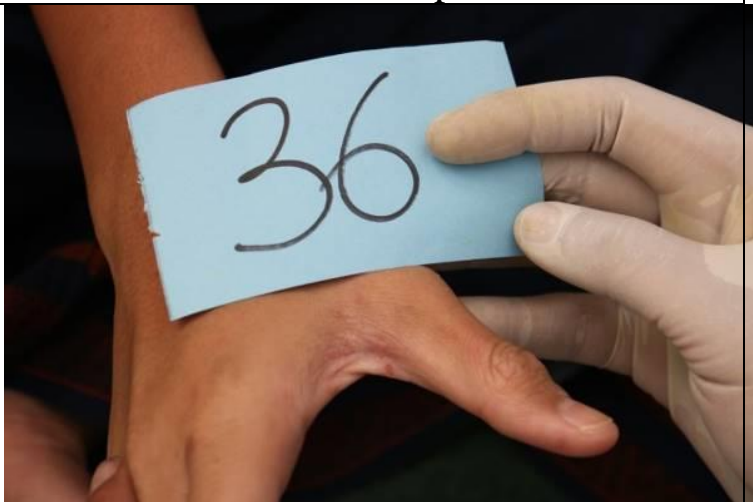

Sesudah terapi A

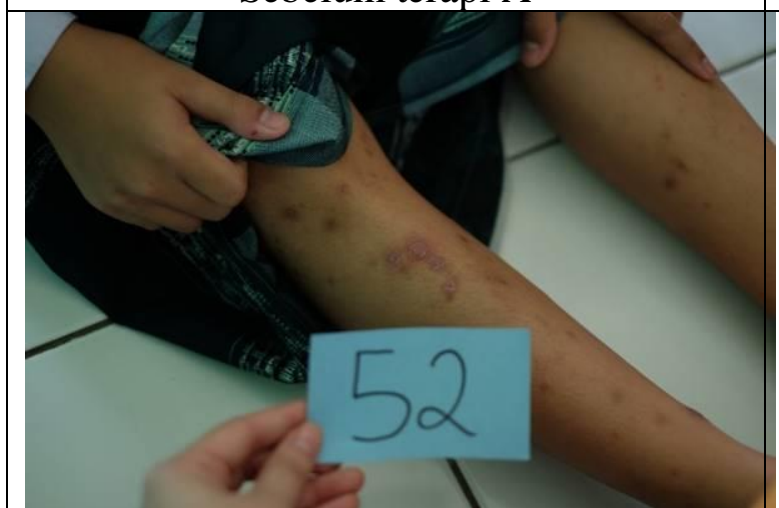

Sebelum terapi A

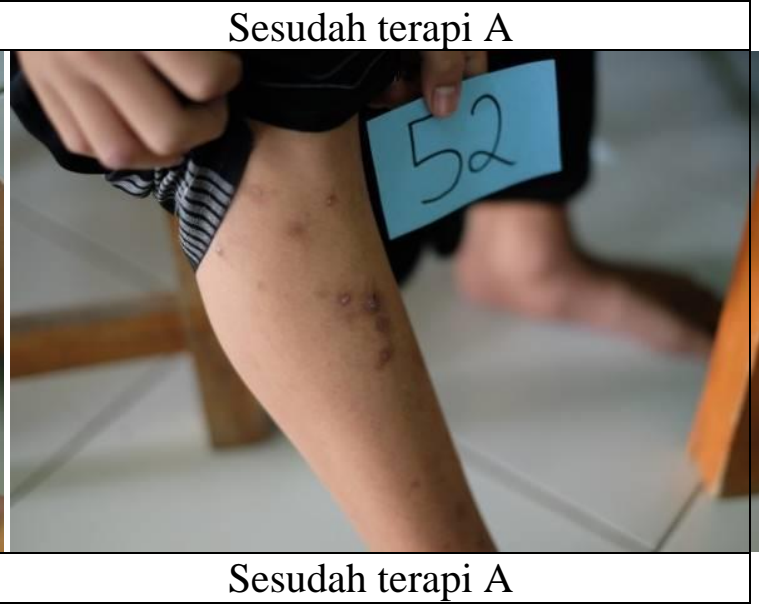




\begin{tabular}{|l|}
\hline Research Article \\
\hline
\end{tabular}

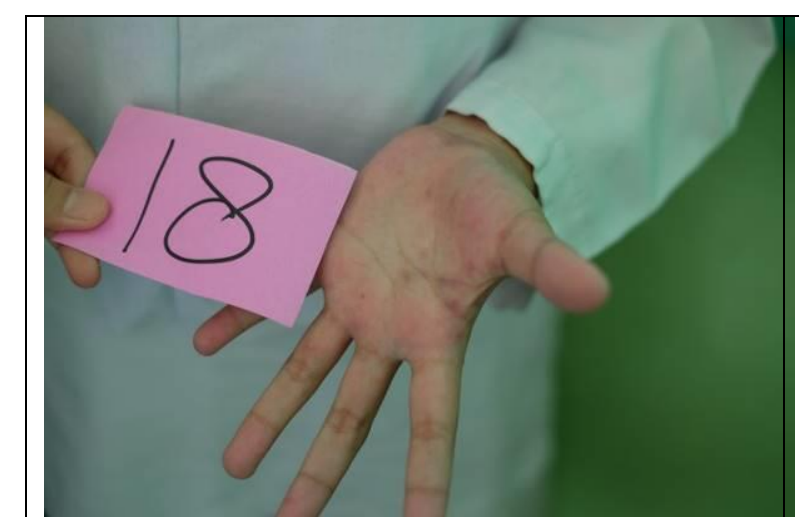

Sebelum terapi B
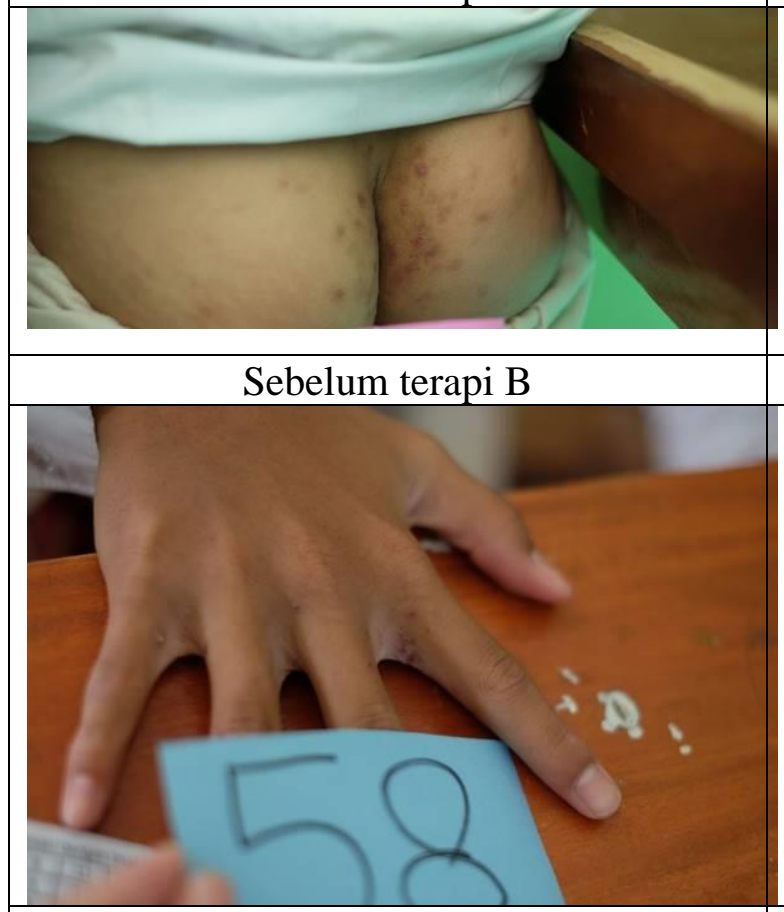

Sebelum terapi B

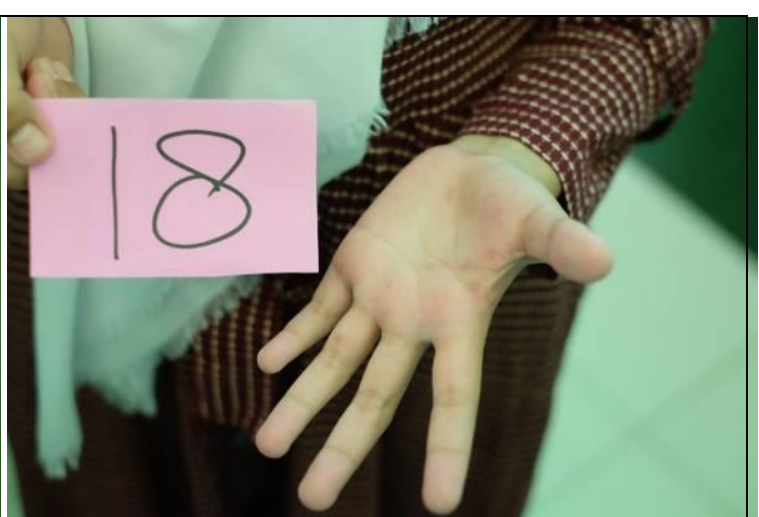

Sesudah terapi B

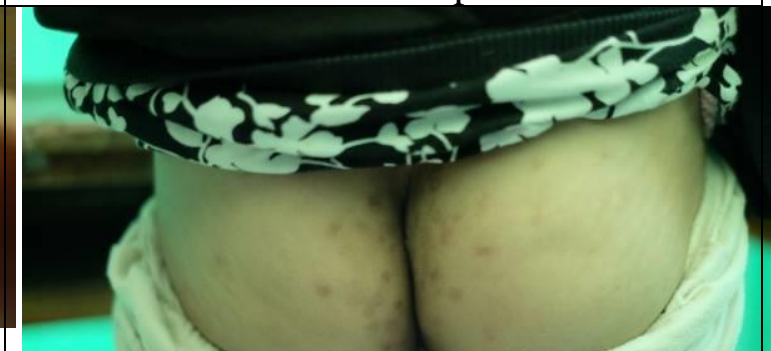

Sesudah terapi B

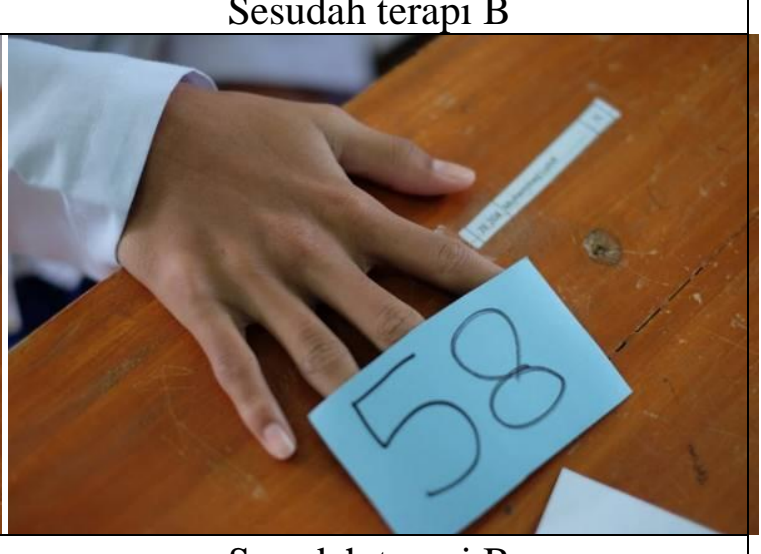

Sesudah terapi B

Gambar 1 Dokumentasi Hasil Penelitian Perbandingan Antiskabies Krim A dan Krim B

Keterangan:

Foto perbandingan sebelum dan sesudah pemberian obat krim A dan B

\section{Diskusi}

Skabies merupakan penyakit yang disebabkan infestasi dan sensitisasi pada kulit manusia oleh tungau Sarcoptes scabiei var. hominis. Penyakit ini masih sering dijumpai di Indonesia, serta masih menjadi masalah kesehatan masyarakat. Prevalensi skabies meningkat pada anak-anak, diikuti dengan usia pubertas, dan dewasa muda. Penyakit ini terutama terjadi 


\section{Research Article}

pada lembaga institusional, seperti penjara, rumah jompo, tempat penitipan anak, asrama sekolah, dan rumah yatim piatu. ${ }^{10}$

Gejala utama penyakit ini adalah gatal yang dirasakan terutama pada malam hari. Rasa gatal dapat muncul sebelum timbulnya lesi kulit. Kelainan kulit pada penderita skabies adalah papula, nodul, vesikopustula, dan kunikulus. Lesi dapat juga berupa skuama, krusta, dan ekskoriasi. Adanya kunikulus merupakan lesi patognomonik skabies. Kunikulus ini dapat tampak berupa garis-garis pendek, berkelok-kelok, berwarna coklat, dengan panjang kurang dari satu sentimeter. Tungau dapat ditemukan pada ujung kunikulus yang berupa vesikel atau pustula, dan sedikit menimbul dari permukaan. ${ }^{7,8}$

Diagnosis ditegakkan berdasarkan anamnesis dan pemeriksaan fisik. Terdapat 4 tanda kardinal untuk diagnosis skabies yaitu pruritus nokturna, menyerang sekelompok manusia, adanya gambaran polimorfik/ kunikulus pada daerah predileksi lesi di stratum korneum yang tipis (sela jari, pergelangan volar tangan dan kaki, dsb), dan ditemukannya tungau pada pemeriksaan mikroskopis. Diagnosis dibuat dengan menemukan 2 dari 4 tanda kardinal tersebut. ${ }^{6,10,11}$

Hasil penelitian ini menunjukkan perbaikan bagi penderita skabies baik dengan terapi krim A maupun dengan terapi krim B. Pemberian krim B memberikan hasil skor yang lebih baik yaitu rata-rata 1,4 yang menunjukkan perbaikan penderita lebih baik dibandingkan pemberian terapi krim A dengan skor 1,7.

Pemberian terapi krim B memberikan kesembuhan penderita yang ditandai dengan tidak adanya gatal dan lesi sebanyak 17 orang dari 30 orang subjek penelitian, atau sebesar 56,67\%. Pemberian terapi krim A memberikan kesembuhan pendertita yang ditandai dengan tidak adanya gatal dan lesi sebanyak 9 orang dari 30 orang subjek penelitian, atau sebesar $30 \%$. Hal ini menunjukkan bahwa pada penelitian ini terapi krim B lebih baik dibandingkan pemberian terapi krim A, dengan perbedaan yang signifikan secara statistik $(p<0,05)$.

Setelah penelitian selesai, diinformasikan bahwa krim antiskabies A adalah obat yang mengandung Permethrin 5\%, sedangkan krim antiskabies B mengandung Permethrin 5\% + asam usnat $1 \%$.

Penambahan asam usnat pada Permethrin ternyata memberikan hasil pengobatan yang lebih baik dibandingkan Permethrin dalam bentuk tunggalnya. Aktivitas antibakteri asam usnat menambah efektivitas Permethrin suatu pembunuh serangga, dalam hal ini Sarcoptes scabiei. Hal ini terbukti pada penelitian ini, bahwa pemberian krim yang mengandung kombinasi 
Permethrin 5\% dan asam usnat $1 \%$ lebih efektif dibandingkan krim yang hanya mengandung Permethrin 5\% $(\mathrm{p}<0,05)^{7,8}$

Penelitian serupa yang pernah dilakukan adalah penelitian yang membandingkan efektivitas terapi aplikasi topikal 5\% Permethrin dengan pemberian Ivermectin (200 $\mu \mathrm{g} / \mathrm{kg} /$ dosis) per oral dan kombinasinya. Jumlah subjek penelitian sebanyak 120 orang yang secara klinis didiagnosis sebagai kasus skabies (> usia 5 tahun dan/atau > $15 \mathrm{~kg}$ ) yang secara acak menjadi tiga pengobatan kelompok A, B, C dari 40 penderita masing-masing; menerima $5 \%$ topikal Permethrin (grup A) atau Ivermectin (200 $\mu \mathrm{g} / \mathrm{kg} / \mathrm{dosis}$ ) per oral dalam dosis tunggal (Grup B) atau kombinasinya (grup C). Hasil penelitian ini tingkat kesembuhan dalam tiga kelompok pengobatan adalah 94,7\% (A), 90\% (B), 89,7\%(C), dan dengan demikian semua modalitas pengobatan tiga sama berkhasiat, namun, pada minggu pertama, penderita Grup A melaporkan perbaikan yang lebih baik dalam jumlah lesi dan berkurangnya rasa gatal. ${ }^{5}$ Pada penelitian ini didapatkan bahwa pemberian terapi krim B memberikan kesembuhan penderita yang lebih baik sebesar 56,67\%. Pemberian terapi krim A memberikan kesembuhan sebesar $30 \%$. Hal ini menunjukkan bahwa pada penelitian ini terapi krim B menunjukan skor lebih baik secara signifikan $(\mathrm{p}<0,05)$ dibandingkan pemberian terapi krim A yang dinilai dengan menghilangnya gatal dan lesi pada penderita skabies.

\section{Simpulan}

Pemberian terapi krim kombinasi Permethrin 5\% dan Asam Usnat 1\% lebih efektif dibandingkan pemberian terapi krim Permethrin 5\% saja.

\section{Daftar Pustaka}

1. Audhah NA, Umniyati SR ddan Siswati AS. Scabies Risk Factor On Students Of Islamic Boarding School. J Buski. 2012;1(4): 14-22

2. Aminah P, Sibero HT dan Ratna MG. Hubungan tingkat pengetahuan dengan kejadian skabies. J Majority. 2015;5(4): 54-9.

3. Mading $\mathbf{M}$ dan Indriaty I. Kajian aspek epidemiologi skabies pada manusua. J Penyakit bersumber binatang. 2015; 2(2):9-17

4. Siti Riptifah dan Mushidah Y. Analisis faktor kejadian Penyakit skabies di pondok pesantren An-Nur Ciseeng Bogor. J Kedokteran dan Kesehatan. 2018; 14(2):74-82

5. Hanna M dan Firza S. Scabies. J Majority. 2016;5(2):37-42.

6. Sharma R, Singal A, Topical Permethrin and oral ivermectin in the management of scabies: A prospective, randomized, double blind, controlled study. Indian J Derm Venereol Leprol. 2011; 77 (5): 581-6

7. Burns DA. Disease Caused by Arthtropods and Other Noxious Animals. Dalam: Burns T, Breathnach S, Cox N, Griffiths C, penyunting. Rook's textbook of dermatology. Edisi ke-8. Wiley-Blackwell; 2010. p 38-45.

8. Krishnan SS. Topical Antiparasitic Agents. Dalam: Wolverton SE, penyunting.Comprehensive Dermatologic Drug Therapy. Edisi ke-3. Indianapolis: Saunders-Elsevier; 2013. p 481-6. 


\section{Research Article}

9. Nuryadi. Dasar-dasar statistik penelitian. Edisi ke-1. Yogyakarta: Sibuku media; 2017.

10. Chikoti MW, Craig NB, Craig GB, Bernard AC. Scabies, other mites and pedicullosis Dalam: Craft N, editor. Fitzpatrick's Dermatology in General Medicine, Ninth Edition.2019.h.3274-86

11. Lupi O. Protozoa and worms. Dalam: Bolognia JL, Jorizzo JL, Rapini RP, penyunting. Dermatology. Edisi ke-2. New York: Elsevier; 2018. 